Florida A\&M University College of Law

Scholarly Commons @ FAMU Law

1999

Regional Security and the Challenges of Democratisation in Africa: The Case of ECOWAS and SADC

Jeremy I. Levitt

Follow this and additional works at: https://commons.law.famu.edu/faculty-research

Part of the International Law Commons, Law and Politics Commons, and the Military, War, and Peace Commons 


\title{
Regional Security and the Challenges of Democratisation in Africa: The Case of ECOWAS and SADC
}

\author{
'Funmi Olonisakin \\ MacArthur Post Doctoral Research Associate, Department of War Studies, King's College \\ London \\ JEREMY LEVITT \\ African Studies Fellow, Centre for International Development and Conflict \\ Management, University of Maryland - College Park
}

In recent years, African leaders have aggressively sought to strengthen their regional security structures while simultaneously attempting to democratise. Although they recognise that African regional organisations will need to assume a greater role in tackling Africa's security problems, the challenges posed by on-going democratisation efforts have had a visible impact on the effectiveness of some regional organisations. This article examines the challenges that democratisation poses to regional collective security arrangements in Africa, with specific reference to ECOWAS and SADC. It argues that whilst the inclination to democratise has influenced the establishment of new collective security structures, the superficial nature of the changes have prevented the gains at the structural level to be translated to meaningful practice on the ground. Nevertheless, some progress has been made.

African states have been compelled to democratise in the post-Cold War environment, where transparency and accountability have gained pre-eminence over historic state sovereignty ideology. At the same time, conflicts that were suppressed by the Cold War system have found free expression. Thus, one main challenge confronting African leaders is the need to re-examine regional security structures in response to the increased incidence of intrastate conflict. The search for effective regional and sub-regional arrangements that may ensure peace and security on the continent has coincided with external demands for Africa to democratise.

Africa's most prominent organisation, the Organisation of African Unity (OAU), and sub-regional actors such as the Economic Community of West African States (ECOWAS) and the Southern African Development Community (SADC) have and are taking steps to establish the necessary mechanisms to respond effectively to both intrastate and interstate conflict. In 1993, the OAU created the Mechanism for Conflict Prevention, Management and Resolution (OAU 
Mechanism). Likewise, the ECOWAS Revised Treaty of 1993 made provision for the establishment of a regional collective security mechanism, and in 1998 it established a Mechanism for Conflict Prevention, Management, Resolution, Peacekeeping and Security (ECOWAS Mechanism). Similarly, in 1996, SADC instituted an Organ for Politics, Defence and Security (Organ), and in 1997 supplemented it with a Protocol on Politics, Defence and Security (Protocol). Such organisations face serious political and economic challenges, as their member states struggle to develop and democratise amidst harsh domestic circumstances, and under the scrutiny of coercive financial institutions and donor governments. Clearly, the obligations of democratisation have affected the ability of African regional actors to maintain peace and security. This article examines how the challenges of democratisation have and will influence the structure and works of ECOWAS and SADC.

\section{Regional security in the Cold Warera}

\section{The $O A U$}

During the Cold War, states were concerned primarily with interstate as opposed to intrastate security issues. The domestic affairs of states were arguably of secondary importance in the international system, where political and economic ideology and alignment took precedence over the need to construct viable and accountable regimes.

In Africa, as in other regions, security was seen largely within the context of interstate relations. The need for states to maintain their territorial integrity and political independence was at the core of regional security concerns in Africa. The urge by some states to redraw the artificial boundaries inherited from their colonial masters coupled with ethnic claims for self-determination posed new security dilemmas on the continent. Thus, the OAU's primary concern was safeguarding of the international law principles of state sovereignty, territorial integrity and non-intervention. The solidification of the inherited frontiers resulted in perhaps one major benefit: it prevented several intrastate conflicts from evolving into interstate catastrophes.

The founding members of the OAU adopted a long-term geopolitical strategy that guaranteed the political independence of their states but inhibited authentic democratisation. The majority of the newly appointed African Heads of State and Government appeared to be preoccupied with serving the metropolis of their former colonial masters (e.g., Omar Bongo in Gabon), or increasing their personal wealth and that of foreign banking institutions (e.g., Sese Mobutu in former Zaire). Hence, Kwame Nkrumah's proposals for a United States of Africa and African High Command received only modest support. ${ }^{1}$ OAU leaders were reluctant to cede their sovereignty to a supranational government, having only just emerged from colonial domination. In this sense, the OAU Charter reflected the political sensitivity of its member states.

During the Cold War, individual human security was overshadowed by African preoccupations with state security. Human security was regarded as a purely 
internal issue, as the principle of non-interference took precedence in the formulation of security policy in Africa and the West. The net result was that many African leaders could not be held accountable for repressing and exploiting their populations. Furthermore, since the majority of African regimes were authoritarian, it was highly unlikely that such regimes would seek to enforce the rule of law on others.

In the immediate post-independence era, several African regimes maintained a tight grip over their internal security/affairs to shield themselves from the revolutionary fervour that was sweeping the continent. Many leaders preferred authoritarian patterns of governance to democratic ones, usually in the form of one-party states, and their repressive policies received limited attention from the international community, which was preoccupied with the politics of the Cold War. Therefore, in Angola, Mozambique, Liberia, Sierra Leone, South Africa, Zaire (now The Democratic Republic of the Congo, DRC) and others, authoritarian regimes thrived at the expense of their civilian populations. It was common place for authoritarian regimes to violently suppress internal opposition and ignore demands for democratisation. On the eve of the end of the Cold War, forty-two out of forty-seven regimes in sub-Saharan Africa were non-democratic. ${ }^{2}$

The OAU Charter did not provide for adequate measures to deal with internal conflict scenarios, which in most cases were a by-product of the repressive policies of OAU leaders. As members of the highest decision-making body in the OAU - the Authority of Heads of States and Governments - member states were secure in knowing that there were no institutional checks on their power. Six of the seven fundamental principles enumerated in Article III of the OAU Charter ensure the sovereignty of its member states, and in principle, prevent them from interfering in the internal affairs of other members. This reality was reinforced by the Cold War system, which as previously mentioned, was more concerned with ideological positioning than the internal affairs of other states. The end result was the absence of viable security mechanisms to avert state collapse and anarchy.

The OAU's commitment to guaranteeing states rights rather than human rights limited its peacemaking role in situations where internal disputes had escalated into armed conflict, resulting in untold loss of life and state insecurity, as witnessed in Chad and Sudan. This was particularly evident in the fact that the OAU Charter made no provision for peacekeeping. The complex United Nations Operation in the Congo (ONUC) appears to have made many African leaders wary of the concept. Consequently, in 1981, the OAU failed miserably to take decisive action during the Chadian conflict, until it became internationalised when Libya sought to influence its outcome. The reluctance of the OAU to become involved in internal conflicts was also apparent in Angola and Mozambique. Indeed, the OAU's blind support for the recognised governments of both states hampered its ability to respond effectively and impartially to warring in both countries.

\section{ECOWAS and SADC}

ECOWAS was primarily established to promote sub-regional economic integration and development. ${ }^{3}$ Sub-regional security issues were of secondary 
importance. Shortly after it was formed, ECOWAS determined that it could not fulfil its developmental objectives amidst intrastate and interstate instability and insecurity. For example, mercenaries invaded Benin in 1977, and Ghana suffered a major coup d' etat in 1981. These events, amongst others, appear to have influenced ECOWAS to establish a collective security framework. As a result, it adopted a Protocol on Non-Aggression in 1978, which affirmed that it could not 'attain its objectives save in an atmosphere of peace and harmonious understanding among member states of the community'.4 Furthermore, the Protocol states that:

Members States shall, in their relations with one another, refrain from the threat or use of force or aggression, or from employing any other means inconsistent with the Charters of the United Nations and the Organisation of African Unity against the territorial integrity or political independence of other Member-States. ${ }^{5}$

Likewise, in 1981 it adopted the Protocol Relating to Mutual Assistance in Defence, which concluded that 'any armed threat or aggression directed against any member state shall constitute a threat or aggression against the Community'. 6 ECOWAS intended for the Protocols to promote peace and security in the subregion, so that the processes of democratisation could continue unabated. Yet, it did not establish a mechanism to deal with purely internal conflicts as opposed to those that were externally engineered. Akin to the case of the OAU, the political will did not exist to empower states to intervene in the internal affairs of states. Consequently, despotism, cronyism, clientelism and corruption caused weak states to collapse and slide into anarchy, forestalling and prolonging genuine democratisation.

Moreover, colonially inspired anglophone-francophone tensions inhibited sub-regional cooperation. ${ }^{7}$ For example, France provoked geo-linguistic subregional divisions by impelling Burkina Faso, Côte d'Ivoire, Mali, Mauritania, Niger, Senegal and Togo to enter into an agreement on Non-Aggression and Assistance in Defence (ANAD) in 1977, to rival ECOWAS. Until recently, no attempts had been made to harmonise the strategic objectives of both organisations. During the Cold War, domestic and sub-regional security concerns as well as externally induced geopolitical rivalry appears to have inhibited ECOWAS' ability to develop a sound collective security framework, that in turn affected the speed at which most West African regimes sought to democratise. These circumstances had a negative impact on the structural composition of African regimes, as African leaders employed the machinery of the state to preserve their hold on power. This may in part explain why many more authoritarian governments arose than democratic ones.

In Southern Africa, the need to contain the military threat from South Africa lay at the heart of security considerations. Unlike the West African sub-region, Southern Africa was more concerned with the military aspects of security. Subregional security cooperation began with the establishment of the Front Line 
States (FLS) in 1974. The FLS initially included Tanzania and Zambia, but later expanded to include Angola, Botswana, Mozambique, Namibia and Zimbabwe. The main body responsible for implementing FLS policies was the Inter-State Defence and Security Committee (ISDSC) ${ }^{8}$ Democratisation was secondary to the attainment of Black rule in the sub-region, which would not have been possible had the white settler oligarchic regimes in Rhodesia and South Africa continued to broaden their sphere of influence. Hence, the FLS sought to ensure that this would not happen. For example, the mutual defence objectives of the FLS prevented South Africa from maintaining a comfortable foothold in Namibia.

The notion of economic, non-military aspects of security came to the fore later with the advent of the Southern African Development Co-ordination Conference (SADCC) in 1979. SADCC sought to achieve greater economic cooperation in order to reduce its dependence on South Africa. In 1992, SADCC was transformed into the Southern African Development Community (SADC). SADC is primarily concerned with promoting sub-regional political and economic integration and security. With South Africa's transition to democracy in 1994, sub-regional economic issues began to take precedence over security concerns, demonstrating that political stability, i.e. democratisation, is a precondition for economic development.

\section{Post-Cold War restructuring}

The end of the Cold War created new opportunities for African states to restructure their security frameworks. However, it also presented new challenges, as First World states devalued the geopolitical stock of African states. Bipolar politics would no longer play a major role in African security arrangements, and as a result, long standing conflicts could escalate freely in the absence of superpower control. Since the ideological positioning of states was no longer a prerequisite for politico-military and economic rewards, new conditionalities emerged. Democratisation and good governance became preconditions for economic aid. This, taken together with domestic pressures for change brought about a major push for democratisation.

However, some states were not able to make democratic transitions as internal conflicts matured into mass civil war resulting in state collapse, as was the case in Liberia and Sierra Leone. Moreover, serious internal rebellion in Guinea-Bissau and Niger, and political instability in Nigeria further prolonged democratisation. In Southern Africa, some commentators speculated that with the end of the Cold War, peace and stability would return to the region. Majority rule in South Africa and peace in Namibia, Mozambique and Angola (albeit temporary) contributed to this optimism. However, such sentiments were short-lived as warfare in Angola persisted, political discontent in Lesotho erupted, political unrest in Zimbabwe ripened, and the war in the Democratic Republic of the Congo engulfed the subregion. Hence, in the post-Cold War era, West and Southern African regimes have struggled to develop structures that can foster peace and security and promote democratisation and sustainable development. 


\section{Implications for Regional Security Arrangements}

Within and outside Africa, new concepts are being proposed and old ones revised to adjust to the post-Cold War strategic environment. The concept of common security, which emerged in the 1980s, has attracted greater attention in recent years. Supporters of this concept argue that arms build-up will only result in a security dilemma whereby a state's arms build-up forces its neighbour to do the same; a seemingly endless cycle that eventually leads to conflict. ${ }^{9}$ Thus, they claim that states would benefit from reciprocal restraint and Confidence Building Measures (CBM), where states pursue Non-Offensive Defence (NOD) in order to achieve a policy of common security. However, the notion of common security transcends the military realm to include economic, social and environmental aspects of security. The broadening of the security concept to include nonmilitary factors has gained ground in the post-Cold War era. Consequently, a collective security regime is emerging 'where the principles of common security have been adopted by all relevant states within a certain international system or subsystem, ${ }^{10}$ in this respect, ECOWAS and SADC.

For some time, security analysts have attempted to expand the concept of security from its previously narrow militaristic focus to include non-military dimensions. ${ }^{11}$ Today, it is apparent that political, economic and military insecurity in Africa for the most part is a by-product of internal as opposed to external phenomena. State collapse, economic stagnation, corruption, resource scarcity, technological backwardness, overpopulation, ethnic rivalry, environmental degradation, terrorism, crime and disease are all ailments caused by domestic rather than international factors. Caroline Thomas suggests that state-centric approaches to security only identify physical threats outside the territorial boundaries of states, and views military build-up as the response to such perceived challenges. She argues that debt, poverty, environmental and other non-military dimensions should be included in the security calculus. ${ }^{12}$ Barry Buzan suggests that, although the concept of security should be broadened to include non-military dimensions, the state is the principal referent object of security as it forms the framework of order and serves as the primary governing authority. ${ }^{13}$

Yet, before the African state can fulfil its security function adequately, democratic and accountable institutions must be established and maintained so that African civil society may be confident that their basic human needs take precedence over the wants of political elites. In this sense, democratisation is a precondition for long-term internal security. Genuine democratisation cannot, however, take place amidst internal or sub-regional insecurity. Hence, there is a circular causation between collective security and democratisation, which African regional organisations must take into account when formulating a new security policy and creating conflict management mechanisms.

Alternative concepts of common security are being advanced because the collective security system envisaged in the UN Charter for the most part has failed to bring about international peace and security. This is particularly true with 
respect to Africa, which has been left to resolve its own conflicts, whether interstate (e.g., the DRC) or intrastate (e.g., Liberia, Sierra Leone, Guinea-Bissau and Lesotho). The UN has failed dismally to proffer adequate solutions to the latter type of conflict. The underlying premise of the western collective security doctrine presupposes that the aggregated efforts of states will be directed against an aggressor state or be used to remove threats to international peace and security. This doctrine is for the most part a manifestation of western experiences in the First World, not intrastate conflict in the Third. For example, the failure of the USled UN mission in Somalia in 1992 and the Belgium-led UN mission in Rwanda in 1994 are prime examples in this regard. The question remains what type of collective security strategy does Africa need in order for democratic institutions to emerge?

Although African states have begun to respond to the challenges of the new security environment, serious challenges remain. At the very least, the new security situation has demanded a collective recognition of the need for collective security among states at both regional and sub-regional levels. For example, the OAU has determined that it can no longer strictly adhere to the principle of nonintervention when violent conflict, state collapse or anarchy engulf a state. This was certainly the case when a coup d'etat was carried out against the democratically elected government of Tejan Kabbah of Sierra Leone by military junta and the Revolutionary United Front (RUF). In response to these events, the OAU Council of Ministers decided that it '[s]trongly and unequivocally condemns the coup detat [...] and calls for the immediate restoration of constitutional order [and] appeals to the leaders of ECOWAS to assist the people of Sierra Leone to restore constitutional order to the country [... $]^{14}$ It has also established the OAU Mechanism in order to employ a systematic rather than ad hoc approach to conflict resolution. ${ }^{15}$ However, the OAU is still plagued by many of the problems that prevented it from being an effective conflict broker during the Cold War.

Generally speaking, it is difficult for the collective interests of states to coincide on security issues at the regional level (sub-Saharan Africa as a whole) and therefore difficult to obtain consensus, or a common political will to deal with major security dilemmas effectively. In such an environment, a common security agenda is difficult to agree on, let alone implement. However, at the sub-regional level it has been less problematic to pursue such an agenda. For example, South Africa did not have a problem in understanding the efficacy of military intervention in Lesotho. However, it would have been politically taboo for it to intervene in Guinea-Bissau. Invariably, only those states within sub-regions that have common political, economic and military interests are likely to invest in subregional security. Nevertheless, in sub-regional organisations where memberstates have sought to enforce a common security agenda, other challenges have stood in the way of progress. For example, the move towards democratisation among some states (e.g. South Africa), which served as a catalyst for progress in the SADC organisation, has not achieved the same result in ECOWAS, albeit this may change with the coming of a free Nigeria. 


\section{The impact of democratisation on ECOWAS and SADC}

With some exceptions, and to varying degrees, the member states of ECOWAS and SADC have made successful democratic transitions. Democratisation has brought greater international and regional legitimacy to the organisations and their respective sub-regions. In the Southern region, democracy in South Africa spawned the transformation of SADCC into SADC. In addition, the threat of subregional interstate conflict was reduced greatly with a 'free' South Africa, and SADC's politico-military and economic capacity was enhanced significantly.

Democratisation in Southern Africa influenced the objectives of SADC considerably. The inclusion of a democratic South Africa in the new structure coupled with a progressive political climate within a number of the member states, brought about an unprecedented level of sub-regional cooperation. The guiding principles of the organisation, namely that it achieve 'solidarity, peace and security in the region' so that its member may observe 'human rights, democracy and the rule of law, ${ }^{16}$ demonstrate a commitment to promote peace, security and stability to allow for genuine democratisation and development. SADC's holistic approach is very different from the original treaty of ECOWAS, for example, which did not consider the rule of law or democracy seriously.

Furthermore, the establishment of the SADC Organ in June 1996 and the adoption of the SADC Protocol nearly one year later further evidence the organisation's dedication to democracy and sub-regional security. Amongst other goals, the primary objectives of the Organ is to "promote and enhance the development of democratic institutions and practices within member states', 'encourage the observance of universal human rights, and co-operate fully in regional security and defence through conflict prevention, management and resolution'. ${ }^{17}$ In addition, it also seeks to 'develop a collective security capacity and conclude a Mutual Defence Pact for responding to external threats', and 'promote peace-making and peace-keeping in order to achieve sustainable peace and security. ${ }^{18}$ Likewise, the SADC Protocol was adopted to determine the type of measures the Organ would employ if it needed to conduct peace enforcement operations in a state. The Protocol empowers SADC to take forcible military intervention in 'intra-state conflict' to forestall 'large-scale' warring to ensure democracy by protecting the interests of a 'legitimate government'. ${ }^{19}$ The Protocol also permits SADC to take such action in 'interstate conflict' to prevent 'crossborder aggression or the threat of such aggression' or 'disagreement over territorial boundaries. ${ }^{20}$

Until November 1998, with the introduction of the new ECOWAS Mechanism, the situation in the Southern region differed greatly from that of West Africa, where the regional hegemon, Nigeria, had been under the rule of a ruthless and corrupt autocrat. Hence, the ECOWAS Revised Treaty of 1993 and the ECOWAS Mechanism appear to have been manifestations of the organisations sub-regional experiences in Liberia and Sierra Leone as well as external influences from within and outside of the continent rather than the hegemonic conceptions of Nigeria.

The absence of true democratisation in a number of ECOWAS member states, particularly in the sub-regions most populous state, Nigeria, had a significant 
impact on the organisation's activities, most notably in the field of peacekeeping. The ECOWAS Cease-Fire Monitoring Group (ECOMOG) operation in Liberia was novel in many respects. However, it would undoubtedly have been more successful had it been under the direction of responsible and accountable subregional leadership. Although there may have been several reasons why the ECOMOG operation in Liberia encountered problems, ${ }^{21}$ foremost among them was Nigeria's authoritarian leadership style. This may be attributed to the autocratic character of the Nigerian state, given that it was under General Abacha's rule for the latter five years of the operation.

Some of the failures of ECOWAS in Liberia (and to a lesser extent Sierra Leone) clearly emanated from the management of the operation by non-democratic regimes. Both operations were under the political direction of military leaders, which was evident in their overtly offensive character. ${ }^{22}$ In the case of Liberia, for example, the operation lacked legitimacy, impartiality and coherent political direction because it did not include official and unofficial non-military agents on the ground. Moreover, the unilateral decision-making style of Nigeria disrupted the democratic-consensus building channels within ECOWAS. Yet, had Nigeria originally employed a communal approach, it does not appear that such channels would have been utilised, since nine of the sixteen member states of ECOWAS were under military rule at the time of the intervention, and the majority of others could be categorised as authoritarian regimes. In fact, some of the member states of ECOWAS were determined to prevent civilian-led insurrections from unseating military regimes in the sub-region. ${ }^{23}$ All but one of the members of the Standing Mediation Committee, which initiated the ECOMOG operation and initially was responsible for its management, were governed by authoritarian regimes. ${ }^{24}$

Today, ECOWAS is a more effective organisation than it was in the early and mid-1990s because many states that were previously under authoritarian rule have made democratic transitions (e.g. Nigeria, Guinea, Ghana and Mali), and internal conflict has been replaced by democratisation in those states that were formerly engulfed in war (e.g. Liberia and Sierra Leone). From a regional security perspective, the ECOWAS missions in Liberia, Sierra Leone and Guinea-Bissau have prevented the sub-region from descending into absolute chaos. Nevertheless, ECOWAS may still be classified as an ineffective organisation, akin to the OAU, due to its legacy of adopting popular and progressive liberal democratic instruments of grand political, economic and social significance, but not mustering the political will to implement them. This phenomenon may be ascribed to the influences of bad leaders and corrupt regimes, the majority of which, today, seem to reside in francophone African states.

However, the adoption of the ECOWAS Mechanism may signal a progressive change in the attitudes of ECOWAS leaders as it is by far the most advanced and authentically African regional collective security mechanism on the continent. It is clear that the Mechanism was introduced as a result of the sub-regional experiences of ECOWAS-ECOMOG in Liberia and Sierra Leone, and that due consideration and respect were given to the rule of law and democracy. For example, Article 46 of the Protocol, which deals with 'internal situations', i.e. 
purely internal conflicts, indicates that ECOWAS may intervene forcibly in states when a situation poses 'a serious threat to peace in the sub-region' or erupts following the 'overthrow or attempted overthrow of a democratically elected government. ${ }^{25}$ Hence, with a free Nigeria to lead the sub-region, the ECOWAS would appear to be in a viable position to foster security, stability and development, objectives it has longed to meet for nearly twenty-five years.

\section{The ghost of autocracy and dilemmas for sub-regional hegemonies}

With few exceptions, progress towards democratisation has been largely cosmetic in those countries that have experienced multiparty elections. ${ }^{26}$ Intimidation of opposition groups and the press, and continued violations of human rights ensure that old tensions remain. In the West African sub-region, Ghana and Mali appear to have made the greatest moves towards democratisation, yet in both states, problems persist. In Niger, democratisation efforts were forestalled when President Mainassara was assassinated by members of his presidential guard, resulting in the restoration of military rule. Likewise, in the Southern African region, Presidents Mugabe and Nujoma of Zimbabwe and Namibia respectively would appear poised to stay in power indefinitely. In Angola, warring has continued despite elections.

Superficially, the domestic political situations in these countries would not appear to have an effect on ECOWAS and SADC. Yet, the implications are significant, and the challenges for both organisations are considerable. As previously mentioned, the failure of Nigeria to democratise had a clear impact on the works of the organisation. Paradoxically, had Nigeria been under a civilian democratic government, it is highly unlikely that ECOMOG would have remained in Liberia for seven years and intervened in Sierra Leone in the way that it did, if at all. Nevertheless, had a democratic regime been in power in Nigeria, other African states as well as western donors may have offered the requisite political and economic support to make both operations more effective, thus lessening the burden on Nigeria. The ECOMOG mission in Guinea-Bissau serves as a good example in this regard. Here France provided the necessary economic and logistical assistance to make the operation successful.

The SADC experience has demonstrated how democratisation of the hegemon is an important but not sufficient guarantee for security and development. This is particularly the case when its hegemony is in dispute (e.g. Zimbabwe/South Africa rivalry) and other states are unwilling to commit to the same level of democratisation (e.g. Mozambique and Angola). If regional hegemony is not in dispute, or as in the case of Nigeria, if effective challenge cannot be mounted, such a hegemon may have a profound influence on the workings of the subregional organisation. A responsible and accountable hegemon can have a positive impact on other states within the sub-region and the organisation in which it belongs.

SADC has had a different experience than ECOWAS. Majority rule and democracy in South Africa allowed for the creation of the SADC Organ and adoption of the SADC Protocol. Alternatively, the ECOWAS Mechanism was 
established prior to Nigeria's transition to democracy. Because the SADC instruments were established in an era of peace and security, their genuineness have not been questioned. The ECOWAS Mechanism, on the other hand, has not attained a similar legitimacy because it was instituted at a time when the subregion had not yet shed the yokes of authoritarianism and conflict. Nevertheless, SADC has encountered significant problems with respect to the Organ and Protocol, as South Africa and Zimbabwe have allowed geopolitical rivalry to interfere with the requirements of sub-regional and regional peace and security. The conflict has manifested itself in the debate over the character of the Organ, and has influenced negatively SADC's capacity to evolve a viable solution to the conflict in the DRC.

Another problem of SADC was that, although many of the member states were able to undertake successful democratic transitions, i.e., host majority elections, very few embraced true democratic values. Thus, when Mandela's government suggested that it should be empowered to enforce its own rules (e.g. human rights), many states, which do not have responsible and transparent regimes, opposed the initiative. Several member states have also resented what they consider South African attempts to dominate the sub-region and influence their internal affairs. ${ }^{27}$ Therefore, unless the member states of ECOWAS and SADC begin to place the same emphasis on the interests of the sub-region as on their own, both organisations will continue to struggle to implement their respective objectives competently in the new millennium.

\section{Conclusion}

The above analysis suggests that, as African states democratise, the subregional and regional mechanisms to they belong will attain greater legitimacy and become more effective. Hence, it may be said that there is a circular causation between genuine democratisation and regional security. The two both processes are interrelated and follow a similar logic; peace, security and sustainable development cannot occur in states that have authoritarian regimes and do not observe the rule of law. Authentic democratisation requires that democratic institutions be instituted at every level of civil society, including local, national and even sub-regional levels. Democratic capacity-building must take place in rural as well as urban areas, and African civil society must have the freedom to construct structures that promote human rights, democracy and security. Subregional organisations such as ECOWAS and SADC have a legal, moral and political obligation to ensure that regimes do not violate the rule of law at the expense of their populations, so that the collective will of the citizens may find democratic expression. Liberal democracy necessitates that, as a minimum, governments ensure that the requisite amount of security exists to ensure this expression.

1 Kwame Nkrumah, Africa Must Unite, London, Panaf, 1963, pp. 133-149.

2 The sub-Saharan African countries that were for the most part democratic are as follows: Botswana, Gambia, Mauritius, Senegal and Zimbabwe. 
3 Treaty of the Economic Community of West African States (ECOWAS), Article 2 (1), Lagos, Nigeria, 28 May 1975.

4 ECOWAS, Protocol on Non-Aggression Treaty, 22 April 1978.

5 ECOWAS, Protocol on Non-Aggression Treaty, Article 1.

6 ECOWAS, Protocol Relating to Mutual Assistance on Defence, Chapter II, Article 2, 29 May 1981.

7 Ibrahim A. Gambari, 'The Role of Foreign Intervention in African Reconstruction', in William Zartman, ed., Collapsed States: The Disintegration and Restoration of Legitimate Authority, London, Lynne Rienner Press, 1995.

8 See M. Hough and A. Du Plessis, eds., Selected Documents on Political, Security, Humanitarian and Economic Issues, Pretoria, Institute for Strategic Studies, University of Pretoria, 1996, p. 32.

9 See B. Moller, A Dictionary of Alternative Defence, Boulder, Co., Lynne Rienner Press, 1995, p. 85; A. Butfoy, Common Security and Strategic Reform: A Critical Analysis, London, Macmillan, 1997, pp. 23-37.

10 Moller, A Dictionary of Alternative Defence, p. 86.

11 For a more comprehensive discussion on this issue, see Thomas Jaye and 'Funmi Olonisakin, 'State Rebuilding after State Collapse: Rethinking Security in Post-war Liberia', in Security, Democracy and Development in Post-war Liberia, London, Centre for Democracy and Development, 1998.

12 Caroline Thomas, 'New Directions in Thinking about Security in the Third World', in Ken Booth, ed., New Thinking about Strategy and International Security, London, Harper Collins Academic, 1991, p. 268.

13 See Barry Buzan, 'Is International Security Possible?', in Booth, New Thinking about Strategy and International Security.

14 Organisation of African Unity Council of Ministers Sixty-sixth Ordinary Session, 28-30 May 1997, Harare, Zimbabwe, Draft Decisions, CM/Draft Dec. (LXVI) Rev. 1, at 18.

15 See Report of the Cairo Consultation on the OAU Mechanism for Conflict Prevention, Management and Resolution, Cairo, Egypt, May 1994, p. 19.

16 Treaty of the South African Development Community (SADC), Article 4, Arusha, Tanzania, July 1979.

17 The Southern African Development Community (SADC) Organ for Politics, Defence and Security, Objectives of the Organ (d)(h), Baborne, Botswana, 28 June 1996.

18 The Southern African Development Community (SADC) Organ for Politics, Defence and Security, (i) and (l),

19 Protocol on Politics, Defence and Security in the Southern African Development Community (SADC) Region, Article 5 - Settlement of Disputes, cited in the African Journal of International and Comparative Law, vol. 11, March 1999, pt. 1, pp. 200.

20 Protocol on Politics, Defence and Security in the Southern African Development Community (SADC) Region, Article 5 - Settlement of Disputes, cited in the African Journal of International and Comparative Law, vol. 11, March 1999, pt. 1, pp. 200.

21 Jeremy Levitt, 'Pre-intervention Trust-building, African States and Enforcing the Peace: The Case of ECOWAS in Liberia and Sierra Leone', Liberian Studies Journal, vol. 24, no. 1, 1999.

22 For a detailed discussion of the lack of civilian democratic control of the ECOMOG Operation, see 'Funmi Olonisakin, 'When the Military is the Political Moderator of Peacekeepers', War Studies Journal, King's College London, 1999.

23 Former Guinean Head of State, Lansana Conte, strongly supported the notion that civilians 
should not be encouraged to unseat military rulers. See African Concord, 27 August 1990.

24 Ghana, Nigeria and Sierra Leone were under the military rule of Flight Lieutenant Rawlings, General Babangida and General Momoh respectively, while Mali was under a civilian-led authoritarian regime. The Gambia, which was the only member of ECOWAS that could claim to be democratic, was under the leadership of Dauda Jawara, who had ruled the country since independence.

25 ECOWAS Mechanism for Conflict Prevention, Management, Resolution, Peace-keeping and Security, Section II. Peace-keeping - Article 46, cited in the African Journal of International and Comparative Law, vol. 11, March 1999, pt. 1, p. 158.

26 For a detailed account of the experience with multiparty elections in sub-Saharan Africa, see Nicolas van de Walle and Kimberley Smiddy Butler's article in this special section of the Review.

27 See, for example, The Star, Johannesburg, 12 September 1997; and Mail and Guardian, Johannesburg, 17 July 1997. 